\title{
Monitoring coolant gas composition at TBM-like operating conditions
}

\author{
Regina Krüssmann, Bradut-Eugen Ghidersa \\ regina.kruessmann@kit.edu
}

Europe proposes two helium cooled test blanket modules (TBM) to be installed and tested in ITER.

The composition of the coolant in the Helium Cooling System (HCS) must be constantly monitored.

HELOKA (Helium Loop Karlsruhe) has a design similar to the TBM-HCS and has a Gas Composition Monitoring system that allows taking samples from the loop while the facility is running at nominal parameters $\left(8 \mathrm{MPa}, 300^{\circ} \mathrm{C}\right)$.

In 2019 , during a Breeding Blanket First Wall testing campaign (8MPa and $\left.300^{\circ} \mathrm{C}\right)$, the coolant composition has been measured in parallel with the mock-up testing.

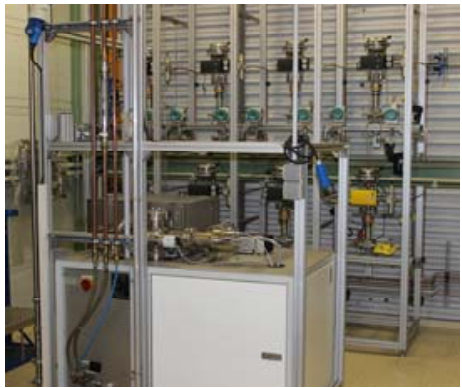

\section{HELOKA Gas Composition Monitoring system:}

- Quadrupole mass spectrometer GAM400, made by InProcess Instruments, Inc., Germany;

- Mass spectrometer connected to the loop in a bypass line to the circulator with a constant through-flow;

- Seven sample lines available, two are connected at the moment;

- An automated sampling procedure is implemented in HELOKA control system allowing the monitoring and control of the valves separating the high pressure helium loop (8MPa) from the (low pressure) mass spectrometer sampling lines $(<0.3 \mathrm{MPa})$.

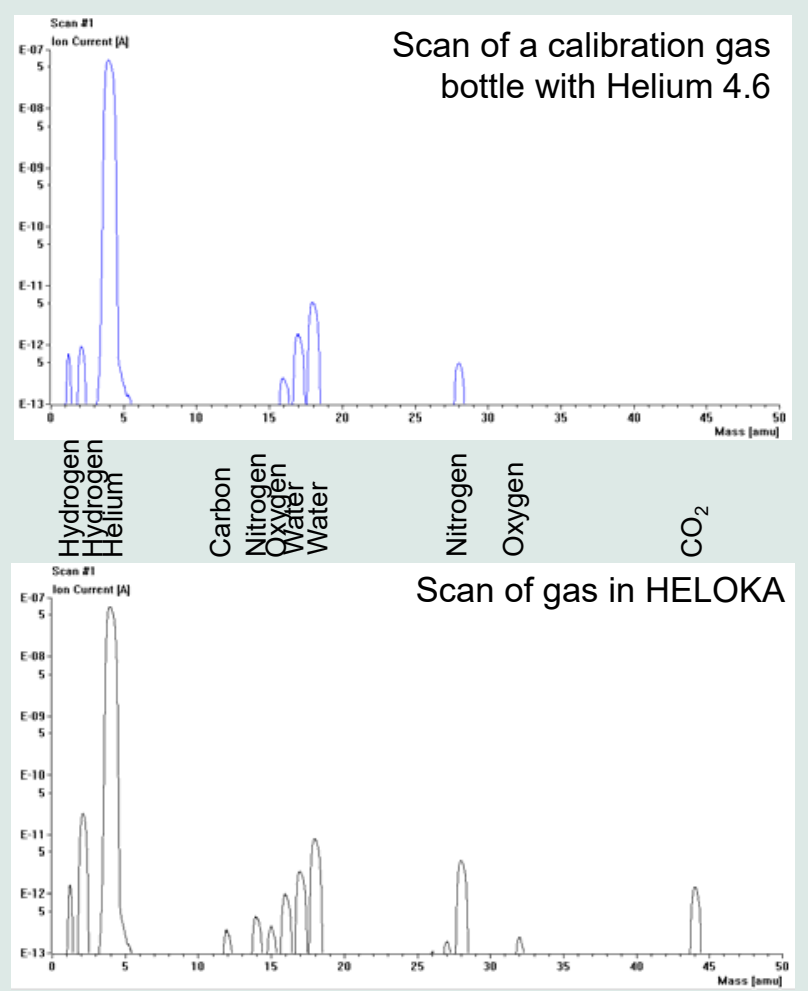

\section{Measurement procedure:}

- Evacuate the mass spectrometer sampling line to the valve that separates it from the loop;

- Open valve to fill the sampling line with gas from the loop up to maximum of $0.3 \mathrm{MPa}$ and maintain that pressure;

- Perform repeated measurements on a small sample from the sampling line.

\begin{tabular}{llll} 
Name & $\begin{array}{l}\text { Reference: } \\
\text { Calibration gas } \\
\text { bottle helium 4.6 }\end{array}$ & $\begin{array}{l}\text { Measured from } \\
\text { HELOKA }\end{array}$ & $\begin{array}{l}\text { Measured 3 } \\
\text { weeks later }\end{array}$ \\
\hline $\mathrm{He}$ & $99.9998 \%$ & $99.9816 \%$ & $99.9813 \%$ \\
\hline $\mathrm{H}_{2}$ & $0.86 \mathrm{ppm}$ & $107.15 \mathrm{ppm}$ & $102.21 \mathrm{ppm}$ \\
\hline $\mathrm{CH}_{4}$ & $0.58 \mathrm{ppm}$ & $2.30 \mathrm{ppm}$ & $2.16 \mathrm{ppm}$ \\
\hline $\mathrm{H}_{2} \mathrm{O}$ & $0.00 \mathrm{ppm}$ & $47.67 \mathrm{ppm}$ & $59.75 \mathrm{ppm}$ \\
\hline $\mathrm{N}_{2}+\mathrm{CO}$ & $0.00 \mathrm{ppm}$ & $17.06 \mathrm{ppm}$ & $15.00 \mathrm{ppm}$ \\
\hline $\mathrm{O}_{2}$ & $0.00 \mathrm{ppm}$ & $1.34 \mathrm{pm}$ & $1.47 \mathrm{ppm}$ \\
\hline $\mathrm{Ar}_{\mathrm{r}}$ & $0.14 \mathrm{ppm}$ & $0.41 \mathrm{ppm}$ & $0.36 \mathrm{ppm}$ \\
\hline $\mathrm{CO}_{2}$ & $0.00 \mathrm{ppm}$ & $7.61 \mathrm{ppm}$ & $5.47 \mathrm{ppm}$ \\
\hline $\mathrm{C}_{\mathrm{x}} \mathrm{H}_{\mathrm{y}}$ & $0.14 \mathrm{ppm}$ & $0.24 \mathrm{ppm}$ & $0.21 \mathrm{ppm}$
\end{tabular}

Results of measurements taken during 18.09.2019 testing campaign 